Useof Active Strategies]. Trud za rubezhom. 2005. № 4.

C. 34-46 (in Russian).

16. Shestakova E.E. Kak trudoustroit pozhilykh?

(Sovremennyy opyt Evropy) [How to Find Employment for the Elderly? (Modern European Experience)]. Rossiya i sovremennyy mir. 2007. № 2. C. 174-183 (in Russian).

17. Allgemeines

Gleichbehandlungsgesetz vom 14. August 2006. URL : https://www.gesetze-im-internet.de/agg/AGG.pdf.

18. Bal P.M. and Visser M.S. When are teachers motivated to work beyond retirement age? The importance of support, change of work role and money. Educational

Management Administration \& Leadership. 2011; 39 (5) : 590-602.

19. Employment Measures for Older People in Japan / Ministry of Health, Labour and Welfare, Japan. URL : http://www.mhlw.go.jp/english/policy/employlabour/employment-security. 20. Healthy life expectancy based on self-perceived health. URL :

https://ec.europa.eu/eurostat/cache/metadata/en/hlth_ silc_17_esms.htm.

21. Inceoglu I., Segers J. and Bartram D. Age-related differences in work motivation. Occupational and

Organizational

Psychology. 2012 ; 85 (2) : 300-329.

22. Main reason for persons who receive a pension to continue working. URL :

http://www.ec.europa.eu/euro stat/data/database.

23. Wang $M$. and

Shultz K.S. Employee retirement: A review and recommendations for future investigation. Management. 2010 ; 36 (1) : 172-206.

24. Word Population Prospects 2019.The United Nations. URL : https://population.un.org/wpp.

Надійшло до редакції 21.11.2020

\section{STUDY OF THE SENSITIZING EFFECT OF DETERGENTS INTENDED FOR THE CARE OF DISHES AND OTHER PRODUCTS FOR CHILDREN}

Holichenkov A.M., Domaratska Yu.S., Hryhorenko L.Yu., Stepanchuk S.V., Liashenko V.I., Maistrenko Z.Yu.

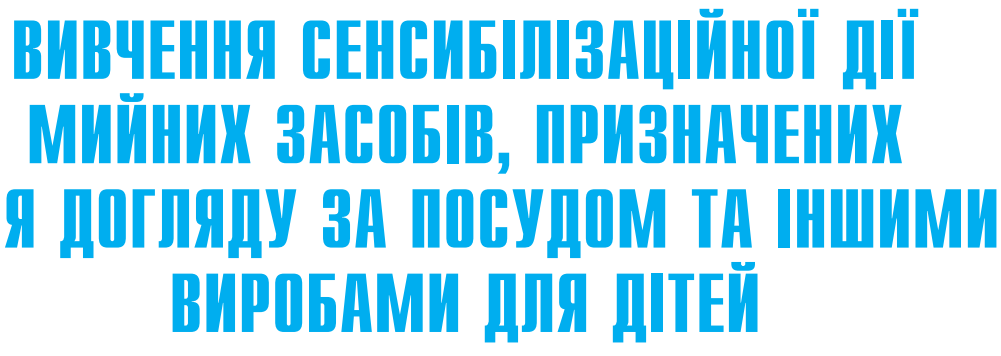

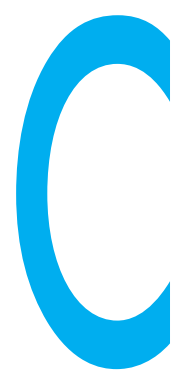

ГОЛІЧЕНКОВ О.М., ДОМАРАЦЬКА Ю.С., ГРИГОРЕНКО Л.Є., СТЕПАНЧУК С.В., ЛЯШЕНКО В.I.,

МАЙСТРЕНКО З.Ю.

ДУ «Інститут громадського здоров'я

ім. О.М. Марзєєва НАМН України», м. Київ тан здоров'я дитячого населення, який характеризується передусім показниками захворюваності дітей та поширеності серед них хвороб, є важливим показником громадського здоров'я. Дані літератури свідчать, що рівні захворюваності дітей за усіма класами хвороб досі залишаються високими і посідають перше місце серед окремих вікових груп населення $[1,2]$. Тому останніми роками все більше ню факторів, що впливають на стан здоров'я дітей.

До чинників, що безпосеуваги приділяється вивчен-

ВИВЧЕННЯ СЕНСИБІЛІЗАЦІЙНОЇ ДІЇ МИЙНИХ ЗАСОБІВ, ПРИЗНАЧЕНИХ ДЛЯ ДОГЛЯДУ ЗА ПОСУДОМ ТА ІНШИМИ ВИРОБАМИ ДЛЯ ДІТЕЙ

Голіченков О.М., Домарацька Ю.С., Григоренко Л.Є., Степанчук С.В., Ляшенко В.І., Майстренко З.Ю. ДУ «Інститутгромадськогоздоров'я ім. О.М. Марзєєва НАМН України», м. Київ

Мета роботи - оцінка сенсибілізаційної дії різних мийних засобів, призначених для догляду за посудом та іншими виробами для дітей.

Матеріалита методи. Дослідження проводились на морських свинках. Сенсибілізацію організму тварин вивчали у реакції де грануляції базофілів периферичної крови (за Шеллі).Для вивчення було обрано $10 \%$ розчини чотирьох засобів для миття дитячого посуду вітчизняного та зарубіжного виробництва (“Аленка», «Карапуз», «Ушастый нянь», «Frosch baby»), придбаних у торговельній мережі супермаркетів м. Києва.

Результати. Проведені за 21 день дослідження дозволили встановити розвиток сенсибілізації організму тварин

(๑) Голіченков О.М., Домарацька Ю.С., Григоренко Л.Є., Степанчук С.В., Ляшенко В.І., Майстренко З.Ю.

СТАТТЯ, 2021. 
редньо можуть вплинути на стан здоров'я дитячого населення, належать товари дитячого асортименту, які нині інтенсивно впроваджуються у товарообіг та населенням у повсякденному житті. На сьогодні серед дитячого асортименту $€$ засоби, призначені для обробки виробів для дітей. засобів їхні залишки можуть потрапляти до організму малюка. А зважаючи на фізіологічні особливості організму дитини (морфологічну та функціональну незрілість шлунково-кишкового тракту та імунної системи), можна говорити про більшу вразливість малюків до несприятливої дії екзогенних факторів [3] .

У попередніх дослідженнях нами було встановлено, що засоби для миття дитячого посуду вимиваються не з усіх матеріалів, отже у подальшому можуть потрапляти через ротову порожнину до організму дитини [4]. Враховуючи вплив мийних засобів на організм, важливим стає питання визначенактивно застосовуються найбільш вживаних товарів При застосуванні таких

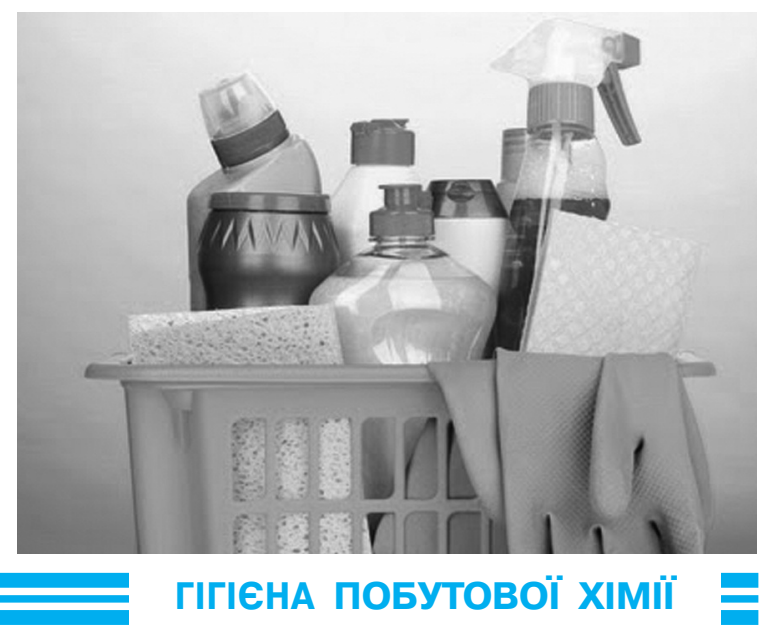

ня їхніх специфічних ефектів.

Метою даної роботи була оцінка сенсибілізуючої дії різних мийних засобів, призначених для догляду за посудом та іншими виробами для дітей.

Матеріали та методи дослідження. Для вивчення сенсибілізуючих властивостей було обрано чотири засоби для миття дитячого посуду вітчизняного та зарубіжного виробництва («Аленка», «Карапуз», «Ушастый нянь», «Frosch Baby»), які відрізняються за відсотковим вмістом аніонних поверхнево активних речовин (АПАР), широко представлені у торговельній мережі, $€$ доступними за ціною .

Усі обрані мийні засоби були придбані у торговельній мережі м. Києва.

\begin{abstract}
дослідних груп, яких піддавали дії розчинів засобів для миття дитячого посуду «Аленка», «Карапуз», «Ушастый нянь», хоча ступінь вираженості ії був різним. Показано, що більш виражені сенсибілізаційн і властивості має розчин мийного засобу «Ушастый нянь», про що свідчить розвиток слабкопозитивної

аутосенсибілізації та позитивної сенсибілізації організму піддослідних тварин.

Вплив на організм морських свинок мийних засобів «Аленка» та «Карапуз» для очищення дитячих виробів призводить до розвитку слабковираженої сенсибілізації, а використання розчину мийного засобу «Аленка» у тварин призводить ще й до розвитку слабковираженої аутосенсибілізації організму.

У групі, де застосовували розчин мийного засобу «Frosh Baby», не було виявлено посилення дегрануляції базофільних гранулоцитів у присутності як тканинного антигена, так і гаптена, що свідчило про відсутність ауто-та сенсибілізації організму тварин цієї групи.
\end{abstract}

Ключові слова: засоби для миття дитячого посуду, сенсибілізація, аутосенсибілізація, гіперчутливість негайного типу.

61 Rovirovinas \& Ileani! № 12021
Для визначення сенсибілізаційної дії обраних мийних засобів нами проведене дослідження можливості розвитку реакції гіперчутливості негайного типу (ГНТ) у непрямому тесті Шеллі. Використаний тест є поширеним серед фахівців через високоінформативність для вивчення сенсибілізації організму за дії різних факторів довкілля [5]. Як антигени у постановці реакції Шеллі використовували гаптени (мийні засоби «Аленка», «Карапуз», «Ушастый нянь», «Frosch Baby») та тканинний антиген - водно-сольовий екстракт тканини шкіри мурчака за методикою приготування, викладеною у роботі [6].

У дослідженні було задіяно 40 статевозрілих мурчаків вагою 450-500 г, яких розподілили на 5 груп по 8 голів у кожній - чотири дослідні та контрольна група. Контрольна група тварин (група 1) зазнавала впливу водопровідної води. Тварини дослідних груп були піддані епікутанним аплікаціям 10\% водних розчинів обраних мийних засобів та розподілялися таким чином: група 2 зазнавала впливу мийного засобу «Аленка», група 3 мийного засобу «Карапуз», група 4 - мийного засобу «Ушастый нянь», група 5 мийного засобу «Frosch Baby». Вибір 10\% розчинів мийних засобів базувався на даних, отриманих нами шляхом вивчення їхньої шкірноподразнювальної дії, які 
свідчили, що застосування у такій концентрації не спричиняє змін функціонального стану шкіри дослідних тварин.

Розчини засобів наносили відкритим аплікаційним способом за температури 1824ㄷ на вистрижену ділянку правої бокової поверхні шкіри кожної тварини (ділянка шкіри - 5 × 5 см, що становить 5\% загальної поверхні шкіри тварини) 3 розрахунку 20 мг/см² поверхні. Експозиція для контрольних і дослідних розчинів становила 4 години щоденно 5 разів на тиждень (за виключенням суботи та неділі) протягом 21 доби. Після закінчення експозиції залишки речовин змивали теплою водою ватним тампоHOM.

Обрахунок даних та аналіз їх проводили з використанням загальноприйнятих методів статистичної обробки результатів меди- ко-біологічних досліджень (з визначенням середньоарифметичних величин показників, стандартної похибки, квадратичного відхилення), параметричних методів перевірки статистичних гіпотез (t-критерій Ст'юдента) [7].

Результати дослідження та їх обговорення. Для обґрунтування вибору водних розчинів мийних засобів «Аленка», «Карапуз», «Ушастый нянь», «Frosch Вaby» нами було проведено вивчення їхньої шкірноподразнювальної дії відповідно до вимог [8].

Для цього на вистрижену ділянку поверхні шкіри лабораторних тварин (мурчаків) щоденно протягом 30 днів здійснювали аплікації 10\%, 25\% та 50\% розчинами досліджуваних мийних засобів.

Щоденне спостереження за шкірою піддослідних тварин, які зазнавали впливу досліджуваних засобів у вигляді нашкірних аплікацій $25 \%$ та 50\% розчинів, показало, що за таких концентрацій у мурчаків реєструється подразнення шкіри. На місцях аплікацій мийними розчинами «Ушастый нянь» і «Карапуз» у тварин візуально спостерігалася гіперемія, нечисленні виразки, мікропластинчасте лу- щення. У мурчаків, яким здійснювали нашкірні аплікації розчинами мийних засобів «Frosch Baby» та «Аленка», було зафіксовано сухість та лущення шкіри.

За дії 10\% водного розчину усіх чотирьох обраних мийних засобів зміна функціонального стану шкіри дослідних мурчаків за 30 днів не спостерігалася - індекс шкірно-подразнювальної дії становив 0 балів.

Візуальне спостереження за мурчаками протягом усього експерименту не виявило відхилень від нормального фізіологічного стану. Поведінкові реакції, а також стан шкіри, шерсті, слизових оболонок залишалися у нормі.

За усіма зовнішніми ознаками дослідні тварини не відрізнялися від контрольних. Мурчаки набирали вагу протягом терміну спостереження. Достовірних відмінностей у прирості ваги тіла між дослідними та контрольними тваринами не відзначено ( $>>0,05)$.

Таким чином, нами було отримано дані, які підтверджують, що епікутанні аплікації обраними мийними засобами у концентрації 10\% не спричиняють змін функціонального стану шкіри дослідних тварин.

Для вивчення впливу до-

\section{Ступінь дегрануляції базофільних гранулоцитів у мурчаків за 21 добу епікутанної дії} $10 \%$ розчинів мийних засобів для дитячого посуду $(\mathrm{n}=8, \mathrm{M}+\mathrm{m})$

\begin{tabular}{|c|c|c|c|c|c|}
\hline \multirow[b]{2}{*}{ Група } & \multicolumn{5}{|c|}{ \% дегранульованих базофілів, ( M \pm m)* } \\
\hline & $\begin{array}{c}\text { тканинний } \\
\text { антиген - шкіра) }\end{array}$ & $\begin{array}{l}\text { гаптен - } \\
\text { «Аленка» }\end{array}$ & $\begin{array}{l}\text { гаптен - } \\
\text { «Карапуз» }\end{array}$ & $\begin{array}{c}\text { гаптен - } \\
\text { «Ушастый нянь» }\end{array}$ & $\begin{array}{c}\text { гаптен - } \\
\text { «Frosch Baby» }\end{array}$ \\
\hline Група 1 - контроль & $2,0 \pm 0,76$ & $2,00 \pm 0,76$ & $1,50 \pm 0,75$ & $2,00 \pm 0,76$ & $2,00 \pm 0,76$ \\
\hline Група 2 - «Аленка» & $11,50 \pm 1,18^{*}$ & $15,00 \pm 0,93^{*}$ & - & - & - \\
\hline Група 3 - «Карапуз» & $9,75 \pm 0,70$ & - & $11,00 \pm 1,00^{*}$ & - & - \\
\hline Група 4 - «Ушастый нянь» & $17,25 \pm 1,46^{\star}$ & - & - & $21,00 \pm 0,93^{\star *}$ & - \\
\hline Група 5 -«Frosh Baby» & $4,75 \pm 0,92$ & - & - & - & $5,75 \pm 2,49$ \\
\hline
\end{tabular}

Примітки: * - від 10\% до $20 \%$ - реакція слабкопозитивна;

** - від 20\% до 30\% - реакція позитивна. 
STUDY OF THE SENSITIZING EFFECT OF DETERGENTS INTENDED FOR THE CARE OF DISHES AND OTHER PRODUCTS FOR CHILDREN

Holichenkov A.M., Domaratska Yu.S., Hryhorenko L.Yu., Stepanchuk S.V., Liashenko V.I., Maistrenko Z. Yu. State Institution "O.M. Marzieiev Institute for Public Health, NAMS of Ukraine", Kyiv Objective: We evaluated the sensitizing effect of various detergents intended for the care of dishes and other products for children.

Materials and methods: The study was carried out in guinea pigs. The sensitization of the animal's organism was studied in the reaction of degranulation of peripheral blood basophils (after Shelley). For the study, we selected $10 \%$ solutions of domestic and foreign products for washing children's dishes («Alionka», "Karapuz», "Ushastyi Nian», «Frosch Baby») purchased in the supermarkets of Kyiv.

Results: In 21 days, the performed study made it possible to establish the development of sensitization of the organism of the animals in the experimental groups exposed to the solutions of the detergents "Alionka»,
«Karapuz», «Ushastyi Nian» for washing children's dishes, although the degree of its manifestation was different. The solution of the detergent «Ushastyi Nian» was shown to possess more pronounced sensitizing properties, as evidenced by the development of weak positive autosensitization and positive sensitization of the organism of the experimental animals.

The impact of the detergents for cleaning childrenMs products "Alionka» and "Karapuz" on the animals' organism leads to the development of mild sensitization, and when using the solution of «Alionka» detergent, a development of the weakly expressed autosensitization of the organism is also observed in the animals. There was no increase in the degranulation of basophilic granulocytes in the presence of both tissue antigen and hapten in the group of animals where the solution of detergent "Frosch Baby» was used, which indicated the absence of auto- and sensitization of the organism of the animals of this group.

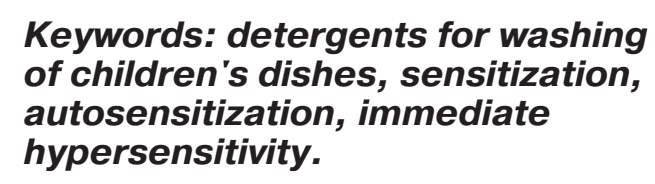

сліджуваних мийних засобів на розвиток сенсибілізації організму за 21 день від початку експерименту здійснювали постановку реакції дегрануляції базофілів периферичної крови (за Шеллі). Результати дослідження розвитку сенсибілізаційних ефектів за дії 10\% водних розчинів обраних мийних засобів наведено у таблиці.

Як видно з представлених у таблиці даних, у мурчаків, які зазнавали впливу 10\% розчину «Аленка», реєструвався розвиток слабкої ГНТ. Про це свідчить підвищення відсотка дегранульованих базофільних гранулоцитів до (15,00 \pm 0,93)\% за дії гаптену відповідного мийного засобу. У тварин цієї дослідної групи спостерігався і розвиток слабковираженої аутосенсибілізації організму, а саме: у присутності тканинного антигена ступінь дегрануляції становив $(11,50$ $\pm 1,18) \%$ (табл.).

Аналіз результатів дослідження сенсибілізаційної дії у тварин, які зазнавали епікутанного впливу 10\% водного розчину мийного засобу «Карапуз», показав: сироватки крови тварин групи 3 викликали розвиток ГНТ до діючого засобу (гаптена), на що вказує підсилення дегрануляції базофілів відносно рівня нормальних величин (у дослідній групі $(11,00 \pm 1,00) \%$, у контролі - (1,50 \pm 0,75)\%). Реакцію можна оцінити як слабкопозитивну. Разом з тим, у тварин дослідної групи 3 не було виявлено антитіл до тканинного антигена, що свідчить про відсутність аутосенсибілізації.

Кількість дегранульованих базофілів у сироватці крови дослідних тварин, які отримували аплікації 10\% розчином мийного засобу «Ушастый нянь», становила $(21,00 \pm 0,93) \%$ у присутності гаптена та $(17,25 \pm$ $1,46) \%$ - у присутності тканинного антигена. Тобто можна констатувати розвиток слабкопозитивної ауто- сенсибілізації та позитивної сенсибілізації організму тварин групи 4.

Вивчення розвитку ГНТ у тварин групи 5 у реакції Шеллі показало, що дія $10 \%$ розчину мийного засобу «Frosch Baby» не викликала підсилення дегрануляції базофільних гранулоцитів у присутності тканинного антигена і гаптена (табл.). Це свідчить про відсутність ауто- та сенсибілізації організму тварин цієї дослідної групи.

Отже, вплив на організм мурчаків мийних засобів для очищення дитячих виробів «Аленка» та «Карапуз» протягом 21 доби призводить до продукції незначної кількості реагінових антитіл. Усі описані сенсибілізаційні ефекти перебували у діапазоні значень $10-20 \%$, що означає наявність слабкопозитивної сенсибілізаційної дії 10\% розчинів мийних засобів «Аленка» та «Карапуз».

У дослідних тварин, які 
ИЗУЧЕНИЕ СЕНСИБИЛИЗИРУЮЩЕГО ДЕЙСТВИЯ МОЮЩИХ СРЕДСТВ, ПРЕДНАЗНАЧЕННЫХ ДЛЯ УХОДА ЗА ПОСУДОЙ И ДРУГИМИ ИЗДЕЛИЯМИ ДЛЯ ДЕТЕЙ

Голиченков А.М., Домарацкая Ю.С., Григоренко Л.Е., Степанчук С.В., Ляшенко В.И., Майстренко З.Ю. ГУ «Институт общественного здоровья им. А.Н. Марзеева НАМН Украины», Г. Киев

Цель работы - оценка сенсибилизирующего действия различных моющих средств, предназначенных для ухода за посудой и другими изделиями для детей.

Материалы и методы. Исследования проводились на морских свинках.

Сенсибилизацию организма животных изучали в реакции дегрануляции базофилов периферической крови (по Шелли). Для изучения были выбраны 10\% растворы четырех средств для мытья детской посуды отечественного и зарубежного производства («Аленка», «Карапуз», «Ушастый нянь», «Frosch Baby»), приобретенных в торговой сети супермаркетов г. Киева.

Результаты. Проведенные через 21 день исследования позволили установить развитие сенсибилизации организма животных опытных групп, которые подвергались воздействию растворов средств для мытья детской посуды «Аленка», «Карапуз», «Ушастый нянь», хотя степень выраженности ее была разной.

Показано, что более выраженными сенсибилизирующими свойствами обладает раствор моющего средства «Ушастый нянь», о чем свидетельствует развитие слабопозитивной аутосенсибилизации и позитивной сенсибилизации организма подопытных животных.

Воздействие на организм морских свинок моющих средств для очистки детских изделий «Аленка» и «Карапуз» приводит к развитию слабовыраженной сенсибилизации, а при использовании раствора моющего средства «Аленка» у животных наблюдается еще и развитие слабовыраженной аутосенсибилизации организма.

В группе, где применяли раствор моющего средства «Frosch Baby», не было выявлено усиления дегрануляции базофильных гранулоцитов в присутствии как тканевого антигена, так и гаптена, что свидетельствовало об отсутсвии ауто- и сенсибилизации организма животных этой группы.

\section{Ключевые слова: средства для мытья детской посуды, сенсибилизация, аутосенсибилизация, гиперчувствительность немедленного типа.}

зазнавали впливу 10\% розчину мийного засобу «Ушастый нянь», відзначалося зростання ефекту аутосенсибілізації. Реакцію можна оцінити як позитивну (ступінь дегрануляції базофілів у групі 4 перебував у межах від 20\% до 30\%).

Водночас у відповідь на дію гаптена реакція була слабковираженою.

Таким чином, проведені дослідження 3 вивчення сенсибілізаційної дії різних засобів для миття дитячого посуду дозволили виявити, що у піддослідних тварин, окрім тих, які зазнавали впливу розчину мийного засобу «Frosch Baby», за 21 день спостерігався розвиток сенсибілізації організму, проте ступінь виразності іiї був різним.

Зважаючи на активне застосування населенням у повсякденному житті синтетичних мийних засо- бів, призначених для обробки виробів для дітей, а також на результати досліджень щодо їхньої несприятливої дії на організм, ми підтримуємо думку, що обґрунтування вимог безпечного застосування таких засобів залишається проблемою, яка потребує нагального вирішення. На нашу думку, одним з кроків на шляху до вирішення цього питання $€$ обовязковим додаток до критеріїв безпеки для товарів побутової хімії, призначених для догляду за виробами дитячої асортиментної групи, адже збереження здоров'я дитини це збереження здоров'я нації. І одним 3 таких показників, який слід враховувати, оцінюючи безпеку синтетичних мийних засобів, призначених для догляду за дитячими виробами, є сенсибілізаційна дія.

\section{Висновки}

1.Визначено що більш вираженими сенсибілізаційними властивостями володіє розчин мийного засобу «Ушастый нянь», про що свідчив розвиток слабкопозитивної аутосенсибілізації та позитивної сенсибілізації організму дослідних тварин.

2. Встановлено, що вплив на організм мурчаків мийних засобів для очищення дитячих виробів «Аленка» та «Карапуз» призводить до розвитку слабкої сенсибілізації, а за дії розчину «Аленка» - ще й до розвитку слабковираженої аутосенсибілізації організму.

3. Показано, що дія розчину мийного засобу «Frosch Baby» не викликала підсилення дегрануляції базофільних гранулоцитів у присутності і тканинного антигена, і гаптена, що свідчить про відсутність 
ауто- та сенсибілізації організму тварин цієї дослідної групи.

\section{ЛІТЕРАТУРА}

1. Панчишин Н.Я. Смирнова В.Л., Галицька О.Я. Захворюваність дитячого населення України та чинники, які впливають на здоров'я дітей. Актуальні питання педіатрії, акушерства та гінекології. 2011. № 2. С. 131-132.

2. Антипкін Ю.Г., Волосовець О.П., Майданник В.Г., Березенко В.С. та ін. Стан здоров'я дитячого населення - майбутнє країни (частина 1). Здоров'я дитини. 2018.

Vol. 13, № 1. $11 \mathrm{c}$.

3. Чеботарева В.Д., Майданник В.Г.

Пропедевтична

педіатрія. К., 1999. С. 45-47. URL : http://www. webmedinfo.ru/propedevtichna-pediatriya-chebotareva-v-d-majdannik-v-g.html

4. Голіченков О.М., Яловенко О.І., Раєцька О.В., Ляшенко В.І., Спаська Ю.С., Уманець Г.П., Майстренко З.Ю., Кучеренко О.Ю. Спосіб оцінки змивання засобів для миття з посуду та інших виробів. К.: Укрмедпатентінформ, 2019. 4 с. (Інформ. лист № 124, 2019).

5. Виноградов Г.И., Винарская Е.И. Науменко Г.М. Реакция дегрануляции базофилов как метод выявления аллергии и аутоаллергии к простым химическим соединениям.

Лабораторное дело. 1989.

№ 6. С. 339-341.

6. Валянський Ю.Л., Чернявський В.І.,

Бірюкова С.Е. та ін. Методи імуноаналізу в інфекційній і клінічній імунології : навчальний посібник. Харків : Стиль-видав, 2011. 112 c.

7. Лакин Г.Ф. Биометрия. Москва: Высшая школа,
1980. C. $96-110$,

142-220.

8. Оценка воздействия вредных химических соединений на кожные покровы и обоснование предельно-допустимых уровней загрязнения кожи : метод. указ. Му 2102-79. Москва, 1979. 23 c.

\section{REFERENCES}

1. Panchyshyn N.Ya.,

Smirnova V.L. and

Halytska O.Ya.

Zakhvoriuvanist dytiachoho naselennia Ukrainy ta chynnyky, yaki vplyvaiut na zdorovia ditei [Morbidity of the Children's Population in Ukraine and Factors Affecting the Health of the Children]. Aktualni pytannia pediatrii, akusherstva ta hinekolohii. $2011 ; 2$ : 131-132

(in Ukrainian).

2. Antypkin Yu.H., Volosovets O.P., Maidannyk V.H.,

Berezenko V.S. et al. Stan zdorovia dytiachoho naselennia - maibutnie krainy (chastyna 1) [The State of Health of the Children - the Future of the Country (Part 1)]. Zdorovia dytyny. 2018 ; 13 (1) : 11 p.

(in Ukrainian).

3. Chebotareva V.D. and Maidannyk V.H.

Propedevtychna pediatriia [Propaedeutic Pediatrics]. Kyiv ;1999 : 45-47 URL : http://www. webmedinfo.ru/pr opedevtichna-pediatriyachebotareva-v-d-majdannikv-g.html

(in Ukrainian).

4. Holichenkov O.M., Yalovenko O.I., Raietska O.V., Liashenko V.I., Spaska Yu.S., Umanets H.P.,

Maistrenko Z.Yu. and

Kucherenko O.Yu. Sposib

otsinky zmyvannia zasobiv dlia myttia z posudu ta inshykh vyrobiv [The Method for the Assessment of the Detergent Flushing of the Dishes and Other Products]. Kyiv : Ukrmedpatentinform ;
2019 : 4 p. (News letter № 124-2019) (in Ukrainian).

5. Vinogradov G.I., Vinarskaya E.I. and Naumenko G.M. Reaktsiya degranulyatsii bazofilov kak metodvy yavleniya allergii I autoallergii k prostym khimicheskim soyedineniyam [Basophil Degranulation Reaction as a Method for the Detection of Allergies and Autoallergies to Simple Chemical Compounds]. Laboratornoye delo. 1989 ; 6 : 339-341 (in Russian).

6. Valianskyi Yu.L.,

Cherniavskyi V.I.,

Biriukova S.E. et al. Metody imunoanalizu v infektsiinii I klinichnii imunolohii : navchalnyiposibnyk [The Methods of Immunoassay in Infectious and Clinical Immunology: Textbook]. Kharkiv : Stylvydav ; 2011 : 112 p.

(in Ukrainian).

7. Lakin G.F. Biometriya [Biometrics]. Moscow : Vysshaya shkola ; 1980 : 96110, 142-220 (in Russian). 8. Otsenka vozdeystviya vrednykh khimicheskikh soyedineniy na kozhnyye pokrovy I obosnovaniye predelno-dopustimykh urovney zagryazneniya kozhi : metodicheskiye ukazaniya MU 2102-79 [Assessment of the Impact of Harmful Chemical Compounds on the Skin and Substantiation of the Maximum Permissible Levels of Skin Contamination: Guidelines MG 2102-79]. Moscow ; 1979 : 23 p.

(in Russian). Надійшло до редакції 28.09.2020 